\title{
OCCURRENCE OF CATONYX CUVIERI (LUND, 1839) (TARDIGRADA, SCELIDOTHERIINAE) IN LATE PLEISTOCENE-HOLOCENE OF BRAZIL
}

\author{
MÁRIO ANDRÉ TRINDADE DANTAS \\ Centro da Terra - Grupo Espeleológico de Sergipe, Rua Antônio Teles da Costa, 42, Bairro Lúzia, 49045-070, \\ Aracaju, SE,Brazil.matdantas@yahoo.com.br \\ MARIA HELENA ZUCON \\ Laboratório de Paleontologia, DBI, UFS, Cidade Universitária Professor José Aloísio de Campos, 49100-000, \\ São Cristóvão, SE, Brazil.zucon@ufs.br
}

\begin{abstract}
In the Brazilian intertropical region, fossils of megafauna occur in tanks and caves. The occurrence of four taxa has been described for a tank in the locality of Fazenda Charco, Sergipe State, and these are: Eremotherium laurillardi (Lund, 1842) (Megatheriidae), Stegomastodon waringi (Holand, 1920) (Gomphotheriidae), Palaeolama major Liais, 1872 (Camelidae) and Toxodontinae (Toxodontidae). With the collection of new material and the review of already existing material from this locality, it was possible to determine the presence of an additional representative of megafauna, namely a sloth of medium size, Catonyx cuvieri. The giant mammal species of the Brazilian intertropical region are generally attributed to the Late Pleistocene, but the occurrence of fauna found in this region could have extended to the beginning of the Holocene.
\end{abstract}

Keywords: Megafauna, Late Pleistocene-Holocene, Poço Redondo, Northeast Brazil.

RESUMO - Na região intertropical brasileira há ocorrência de fósseis da megafauna em tanques e cavernas. Em Sergipe, em um tanque na localidade Fazenda Charco, foi descrita a ocorrência de quatro taxa: Eremotherium laurillardi (Lund, 1842) (Megatheriidae), Stegomastodon waringi (Holand, 1920) (Gomphotheriidae), Palaeolama major Liais, 1872 (Camelidae) e Toxodontinae (Toxodontidae). Com a coleta de novo material e a revisão do já existente desta localidade, foi possível identificar a presença de mais um representante da megafauna, a preguiça de porte médio: Catonyx cuvieri. As espécies de mamíferos gigantes da região intertropical brasileira geralmente são atribuídas ao Pleistoceno final, porém, a fauna encontrada nesta região poderia ter alcançado o Holoceno.

Palavras-chave: Megafauna, Pleistoceno final-Holoceno, Poço Redondo, nordeste brasileiro.

\section{INTRODUCTION}

The municipality of Poço Redondo (Figure 1) is located in the northeast of Sergipe State, $185 \mathrm{~km}$ from Aracaju. In this region, the occurrence of tanks is common, which are natural depressions formed by erosion produced along fractures of basal rocks by physical and chemical action (Oliveira \& Hackspacher, 1989).

These tanks are utilized by the local people for the storage of rain water. In the Brazilian intertropical region, the finding of fossils of giant mammals (megafauna) of the Pleistocene in these tanks sometimes occurs when they are excavated by the people to increase the capacity for water retention during the dry season. In the municipality of Poço Redondo, the remains of this fauna have already been found in Fazenda Charco and Fazenda Tytoya (Goes et al. 2002; Dantas \& Zucon, 2005).
The material described in this work came from a tank (9 $\left.{ }^{\circ} 46^{\prime} 56^{\prime \prime} \mathrm{S}, 37^{\circ} 40^{\prime} 62^{\prime \prime} \mathrm{W}\right)$ located on Fazenda Charco (Figures 1 and 2), where Goes et al. (2002) already identified the following taxa: Eremotherium laurillardi (Lund, 1842) (Megatheriidae); Stegomastodon waringi (Holand, 1920) (Gomphotheriidae); Palaeolama major Liais, 1872 (Camelidae); and Toxodon sp. Owen, 1840 (Toxodontidae).

New prospecting was conducted, as well as a review of material previously collected and studied, making it possible to identify the new material (a distal fragment of the right humerus) as belonging to another Tardigrada, Catonyx cuvieri, which is described in this work.

The fossil studied here was deposited in the scientific collection of the Laboratório de Paleontologia da Universidade Federal de Sergipe (LPUFS), in São Cristóvão, Sergipe State, Brazil. 


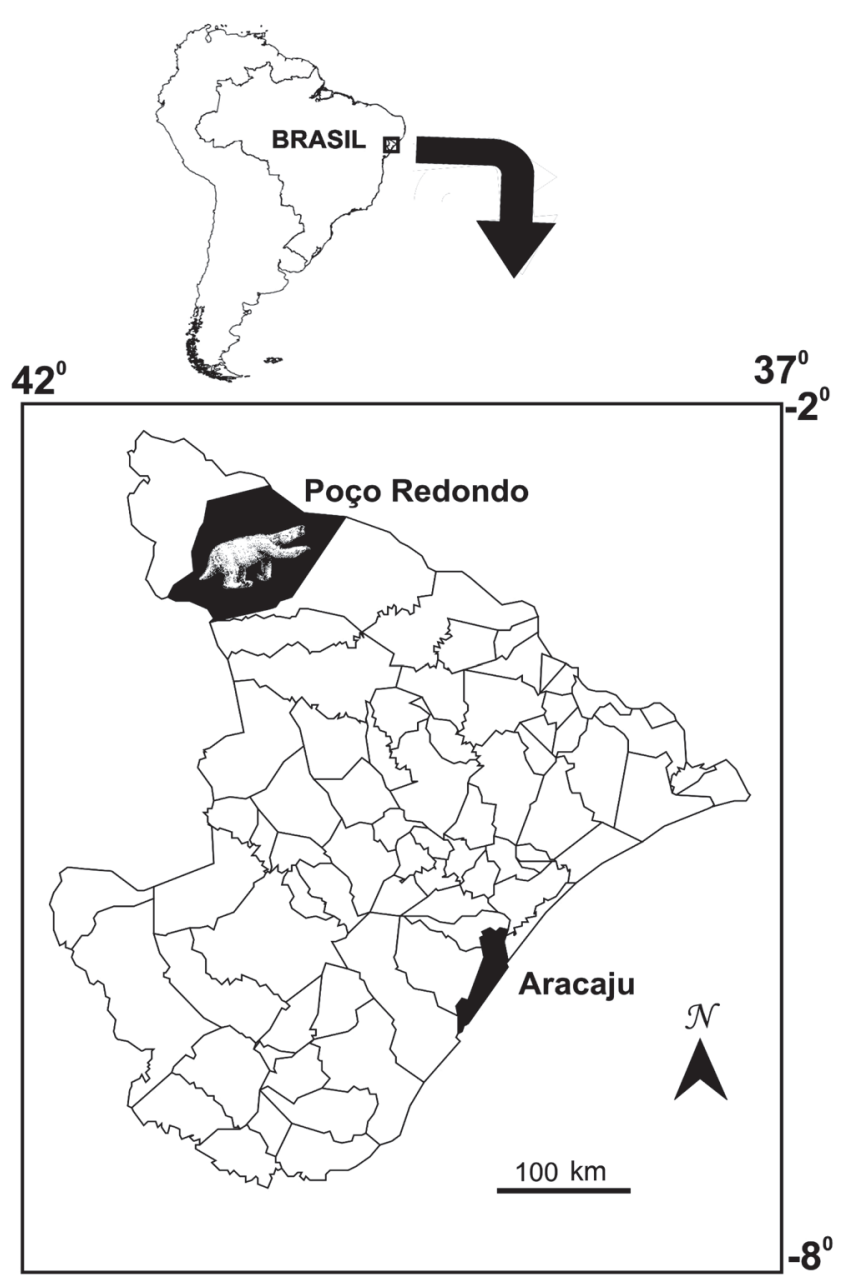

Figure 1. Location map of the muicipality of Poço Redondo, in Sergipe State, Brazil.

\section{PALEONTOLOGIC SYSTEMATICS}

\author{
TARDIGRADA Latham \& Davies, 1795 \\ MYLODONTOIDEA Gill, 1872 \\ MYLODONTIDAE Gill, 1872 \\ SCELIDOTHERIINAE Ameghino, 1904
}

Catonyx cuvieri (Lund, 1839)

Material. LPUFS 2173, distal fragment of the right humerus (Figure 3).

Description. Of the right humerus LPUFS 2173, only the most distal portion was preserved, which is flat antero-posteriorly and relatively wide. The trochlea is wide $(110 \mathrm{~mm})$, being more than half the maximal width of the distal end $(180 \mathrm{~mm})$. The radial facet is semi-spherical, positioned more distally than the ulnar face which has large cross-section and is less convex than the radial.

The entepicondyle is conspicuous and projects laterally, while the ectepicondyle is smaller and shows the medioproximal portion fractured and lost, thereby making it impossible to observe the supinator crest. The entepicondylar foramen is absent.
Remarks. The systematics of the subfamily Scelidotheriinae is controversial depending on the author, and can include only one genus, Scelidodon ( Sedor et al., 2004); or two genera, Scelidotherium and Catonyx (McDonald \& Perea, 2002; Gaudin, 2004). Also, there can be a variation in the denomination of the genus: Scelidotherium and Scelidodon (Cartelle, 1992; Zurita \& Lutz, 2002). Sometimes, even three genera are considered belonging to this subfamily: Scelidotherium, Scelidodon and Catonyx (Hoffstetter, 1958; Guérin \& Faure, 2004).

The species Catonyx cuvieri has already been described in the states of Rio Grande do Sul, Minas Gerais, Bahia, Alagoas, Paraíba, Piauí and Ceará (Cartelle, 1992; Born et al., 2003; Pereira \& Oliveira, 2003; Guerin \& Faure, 2004). In Sergipe, fossils of this species have been found on Fazenda Elefante, municipality of Gararu (Dantas et al., 2005).

The Scelidotheriinae show a dental formula of $\mathrm{M}^{1-5} / \mathrm{M}_{1-4}$, where their upper and lower molars show a similar size and shape, with the crowns being elliptical or somewhat triangular (Paula Couto, 1979). They constitute a group that can be distinguished from the Mylodontinae by an elongated cranium and by the consequent compression of the dentition (McDonald \& Perea, 2002).

In relation to their postcranium skeleton, the Scelidotheriinae are more graceful than those members of the Subfamily Mylodontinae (Hoffstetter, 1952). The general shape of the humerus resembles that of the Mylodontinae (e.g., Glossotherium and Paramylodon), where the diaphysis is short and the distal portion flat antero-posteriorly and relatively broad. Thus, the Scelidotheriinae show a constant proportion between the length of the humerus and the width of the distal epiphysis, and differ in having a well-developed entepicondylar foramen and being smaller size in comparison to the Mylodontinae (McDonald, 1987).

Of all the species of the Subfamily Scelidotheriinae, Catonyx cuvieri is the only one that does not have an entepicondylar foramen on the humerus (Paula Couto, 1979; McDonald \& Perea, 2002). Based on this character, on its measurements and on the record of this species at various Pleistocene localities in Brazil, the fragment of the humerus (LPUFS 2173) studied here is attributed to Catonyx cuvieri.

\section{PALEOECOLOGICAL INFERENCES}

Silva (2001) determined $\delta{ }^{13} \mathrm{C}$ in the molars of E. laurillardi, $S$. waringi and T. platensis and confirmed that the first two species showed a diet based mainly on grasses (C4 plants), while T. platensis fed on aquatic macrophytes (C3 plants) as well as grasses. Besides these, Palaeolama major also showed a diet based on grasses (Porpino et al., 2004).

In addition to grasses, E. laurillardi and $S$. waringi also fed on leaves and fruits, where the latter species displayed a broader diet, including also branches of small shrubs (Cartelle, 1992; Prado et al., 2001; Guimarães Jr. \& Galetti, 2001).

Species related to Catonyx cuvieri showed a generalist feeding habit, based on leaves, roots, shrubs or grass (Bargo, 2003). 


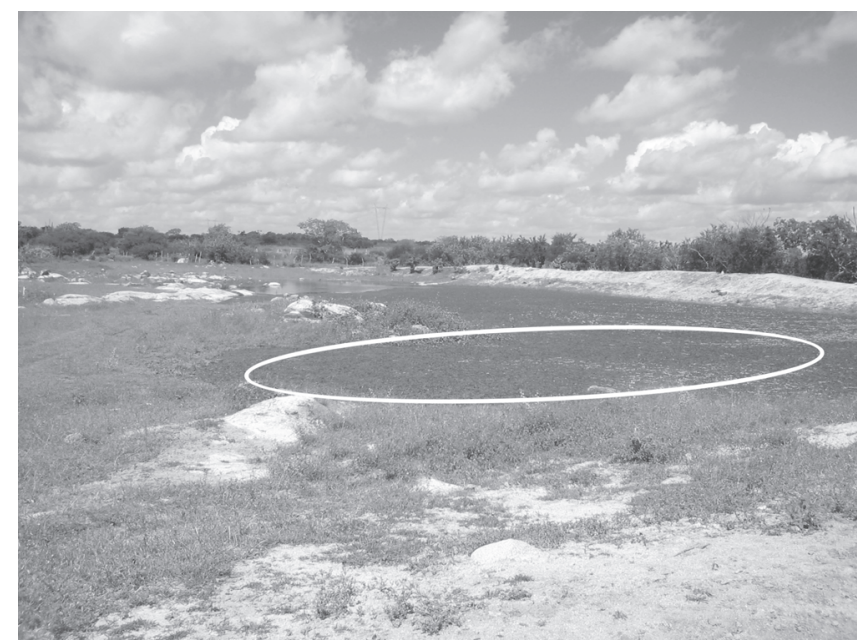

Figure 2. Tank in Charco Farm, municipality of Poço Redondo showing the outcrop (marked by circle) where the material was collected.

\section{TEMPORAL DISTRIBUTION}

This new occurrence makes a total of five taxa identified in the local fauna of Fazenda Charco: E. laurillardi, $S$. waringi, P. major, C. cuvieri and Toxodon sp.

The local faunas found in tanks in other states of Northeast Brazil (e.g., Ceará and Paraíba) are generally attributed to the Late Pleistocene (Bergqvist et al., 1997), but some recent studies suggest a wider age for this fauna, which could be extended up to the beginning of the Holocene.

Some authors (Porpino \& Santos, 2004; Porpino et al., 2004), through faunistic association between current taxa and extinct taxa found in outcrops in the Rio Grande do Norte, classified the fauna found as belonging to the Late Pleistocene-Holocene. Other authors (Faure et al., 1999; Baffa et al., 2000; Barreto et al., 2003), utilizing different dating techniques, found varying ages during the Late Pleistocene-
Holocene for taxa present in the fauna of Northeast Brazil.

The ESR technique was used to date a molar of Toxodon platensis, collected in a cave in São Paulo, indicating an age of approximately 6,700 years (Baffa et al., 2000). In utilizing the same technique, Barreto et al. (2003) dated two molars of Haplomastodon (=Stegomastodon) and one of Macrauchenidae Xenorhinotherium bahiense Cartelle \& Lessa, 1988, found in a tank in the interior of Paraíba, obtaining ages of approximately $26,000,15,000$ and 32,000 years, respectively.

Also carried out were two datings of concentrations of organic matter collected in sediments of Toca do Serrote do Artur (São Raimundo Nonato, Piauí), where the ages varied between approximately 8,500 and 6,900 years. In this locality, the remains were found of a fauna composed of Dasypus, Propraopus, Hoplophorus, Glyptodon, Conepatus, Panthera, Equus, Dicotyles, Tayassu and Palaeolama (Faure et al., 1999).

Therefore, these results support the idea that the fossil species of the Quaternary occurring in the Brazilian intertropical region show a more encompassing temporal distribution which could have extended up to the beginning of the Holocene.

\section{FINAL CONSIDERATIONS}

Recorded in a tank on Fazenda Charco, in the municipality of Poço Redondo, Sergipe State, Brazil, was the occurrence of the species Catonyx cuvieri, in association with $E$. laurillardi, S. waringi, P. major and Toxodon sp.

The paleoecology of these species suggests that the environmental conditions of this region during the Late Pleistocene-Holocene different from those of today, comprising an environment of a cerrado of shrub communities, open savannas and fields, where the tanks served as natural sources of water.
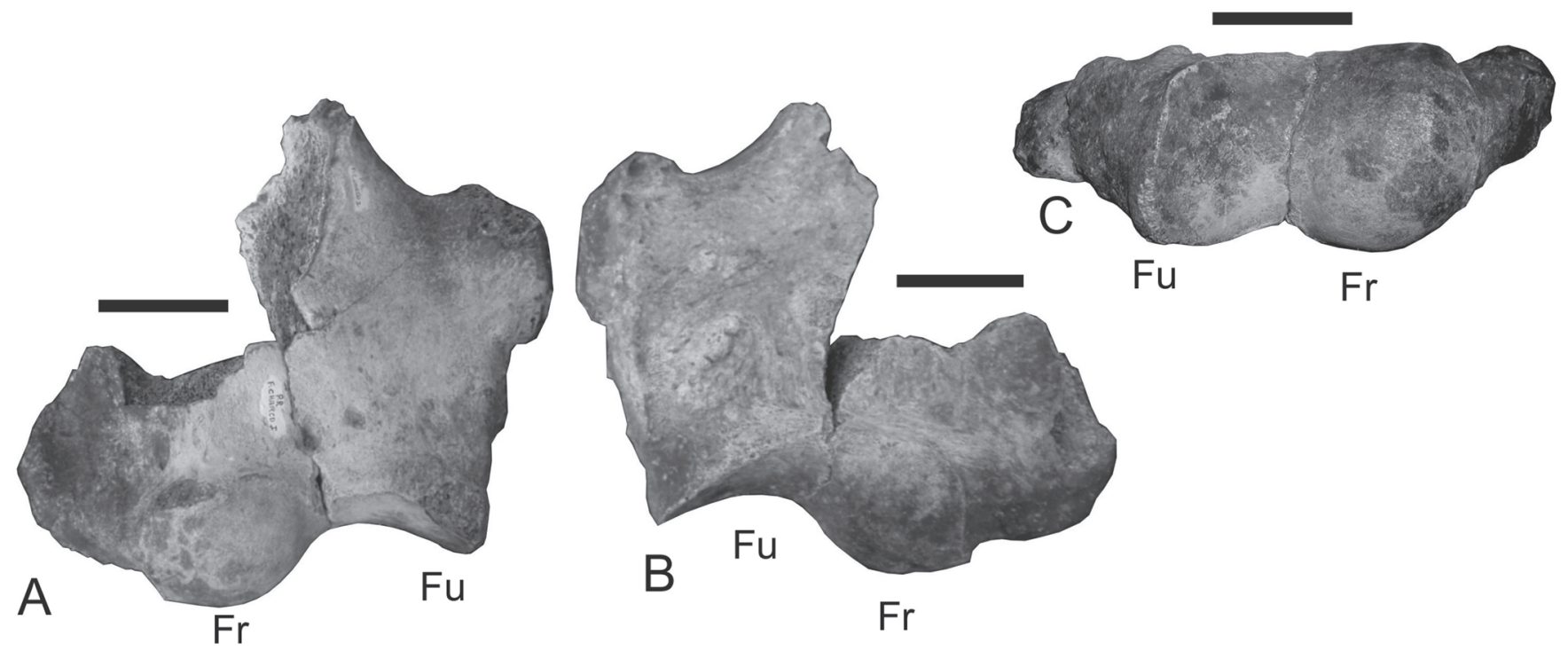

Figure 3. Catonyx cuvieri, distal portion of right humerus, LPUFS 2173, in anterior (A), posterior (B), and distal (C) views. Abbreviations: Fu, ulnar surface; Fr, radial surface. Scale bar $=50 \mathrm{~mm}$. 


\section{ACKNOWLEDGMENTS}

The authors would like to thank the anonymous reviewers for the critical reading of the manuscript.

\section{REFERENCES}

Baffa, O.; Brunetti, A.; Karmann, I. \& Dias Neto, C.M. 2000. ESR dating of a Toxodon tooth from a Brazilian karstic cave. Applied Radiation and Isotopes, 52:1345-1349.

Bargo, M.S. 2003. Biomechanics and Palaeobiology of the Xenarthra: the state of the art. Senckenbergiana biológica, 83(1):41-50.

Barreto, A.M.F.; Almeida, J.A.C. de; Silva, F.M. da; Kinoshita, A.; Baffa, O. \& Macário, J. 2003. Datação por ESR em dentes de Haplomastodon e Xenorhinotherium de Lagoa de Dentro, Puxinamã, Paraíba. In: CONGRESSO BRASILEIRO DE PALEONTOLOGIA, 18, 2003. Boletim de Resumos, Brasília, UNB, p. 60-61.

Bergqvist, L.P.; Gomide, M.; Cartelle, C. \& Capilla, R. 1997. Faunas locais de mamíferos pleistocênicos de Itapipoca/Ceará, Taperoá/ Paraíba e Campina Grande/Paraíba. Estudo comparativo, bioestratinomico e paleoambiental. Revista Universidade Guarulhos, Geociências, 2(6):23-32.

Born, P.A.; Neto, C.M.E.D. \& Pellaes, F. 2003. Registro de mamíferos pleistocênicos no estado de Alagoas, nordeste do Brasil. In: CONGRESSO BRASILEIRO DE PALEONTOLOGIA, 18 , 2003. Boletim de Resumos, Brasília, UNB, p. 81.

Cartelle, C. 1992. Edentata e megamamiferos herbivoros extintos da toca dos ossos (Ourolândia, BA). Programa de Pós-Graduação em Morfologia, Universidade Federal de Minas Gerais, $\mathrm{PhD}$ Dissertation, $516 \mathrm{p}$.

Dantas, M.A.T. \& Zucon, M.H. 2005. Sobre a ocorrência de dois taxa pleistocênicos na Fazenda Tytoya, Poço Redondo, Sergipe. Scientia Plena, 1(4):92-97.

Dantas, M.A.T.; Zucon. M.H. \& Ribeiro, A.M. 2005. Megafauna pleistocênica de Gararu, Sergipe, Brasil. Geociências, 24(3):277287.

Faure, M.; Guérin, C. \& Parenti, F. 1999. Découverte d'une mégafaune holocène à la Toca do Serrote do Artur (aire archéologique de São Raimundo Nonato, Piauí, Brésil). Comptes Rendus de l'Académie des Sciences, Sciences de la terre, 329:443-448.

Gaudin, T.J. 2004. Philogenetic relationships among sloths (Mammalia, Xenarthra, Tardigrada): the craniodental evidence. Zoological Journal of the Linnean Society, 140:255-305.

Goes, F.A.S.; Vieira, F.S.; Zucon, M.H.; Cartelle, C. \& Teodósio, C. 2002. Ocorrência de mamíferos Pleistocênicos em Sergipe, Brasil. Arquivos do Museu Nacional, 60(3):199-206.
Guérin, C. \& Faure, M. 2004. Scelidodon piauiense nov. sp., nouveau Mylodontidae Scelidotheriinae (Mammalia, Xenarthra) du Quaternaire de la région du parc national Serra da Capivara (Piauí, Brésil). Comptes Rendus Paleovol, 3:35-42.

Guimarães-Jr, P.R. \& Galetti, M. 2001. Frutos dispersos por mamíferos extintos. Ciência Hoje, 29(173):83-85.

Hoffstetter, R. 1952. Les mammifères Pléistocènes de la republique de l'Équateur. Mémoires de la Société Géologique de France (nouvelle série), 66:1-391.

Hoffstetter, R. 1958. Xenarthra. In: J. Piveteau (ed.) Traité de Paléontologie, Masson, p. 535-626.

McDonald, H.G. \& Perea, D. 2002. The large Scelidothere Catonyx tarijensis (Xenarthra, Mylodontidae) from the Pleistocene of Uruguay. Journal of Vertebrate Paleontology, 22(3):677-683.

McDonald, H.G. 1987. A systematic review of the Plio-Pleistocene Scelidotheriinae ground sloths (Mammalia, Xenarthra: Mylodontidae). University of Toronto, PhD Dissertation, 478p.

Oliveira, L.D.D. \& Hackspacher, P.C. 1989. Gênese e provável idade dos tanques fossilíferos de São Rafael-RN. In: CONGRESSO BRASILEIRO DE PALEONTOLOGIA, 11, 1989. Anais, Curitiba, UFPR, p. 30-34.

Paula Couto, C. de 1979. Tratado de Paleomastozoologia. Rio de Janeiro, Academia Brasileira de Ciências, 590 p.

Pereira, J.C. \& Oliveira, E.V. 2003. Um Scelidotheriinae (Mammalia, Xenarthra) no Pleistoceno Superior do Rio Grande do Sul. Ameghiniana, 40(4):66R.

Porpino, K.O. \& Santos, M.F.C.F. 2004. Paleovertebrados de Lagoa do Santo, Currais Novos/RN. In: SIMPÓSIO BRASILEIRO DE PALEONTOLOGIA DE VERTEBRADOS, 4, 2004. Boletim de Resumos, Rio Claro, UNESP, p. 51-52.

Porpino, K.O.; Santos, M. de F.C.F. dos; Bergqvist, L.P. 2004 Registros de mamíferos fósseis no Lajedo de Soledade, Apodi, Rio Grande do Norte, Brasil. Revista Brasileira de Paleontologia, 7(3):349-358.

Prado, J.L.; Alberdi, M.T.; Azanza, B.; Sánchez, B. \& Frassinetti, D. 2001. The Pleistocene Gomphotheres (Proboscidea) from South America: diversity, habitats and feeding ecology. In: THE WORLD OF ELEPHANTS INTERNATIONAL CONGRESS, 2001. Annals, Rome, p. 337-340.

Sedor, F.A.; Born, P.A. \& Santos, F.M.S. 2004. Fósseis pleistocênicos de Scelidodon (Mylodontidae) e Tapirus (Tapiridae) em cavernas paranaenses (PR, Sul do Brasil). Acta Biológica Paranaense, 33(1/4):121-128.

Silva, J.L.L. da. 2001. Tafonomia em mamíferos pleistocênicos: caso da planície colúvio-aluvionar de Maravilha - AL. Programa de Pós-Graduação em Geociências, Universidade Federal de Pernambuco, Master Thesis, $96 \mathrm{p}$.

Zurita, A.E. \& Lutz, A.I. 2002. La fauna pleistocena de la Formación Toropí en la Provincia de Corrientes (Argentina). Journal of Neotropical Mammalogy, 9(1):47-56.

Received in February, 2006; accepted in April, 2007. 